УДК 37.011.3:37(091)(493)(092)

DOI:

Галина Кемінь, кандидат педагогічних наук, дочент кафедри мовної та міжкультурної комунікації Дрогобицького державного педагогічного університету імені Івана Франка

\title{
“НОВЕ ВИХОВАННЯ” ЧЕРЕЗ ПРИЗМУ НАУКОВО-ПЕДАГОГІЧНОЇ ДІЯЛЬНОСТІ ОВІДІЯ ДЕКРОЛІ
}

У статті проаналізовано педагогічну спадщину Овідія Декролі та значення його ідей у становленні педагогіки “нового виховання”. Охарактеризовано “нові школи”, метою яких було виховання всебічно розвиненої ініціативної особистості, яка б уміла практично використовувати здобуті знання та самостійно приймати рішення. Розглянуто методи навчання та виховання в діяльності Овідія Декролі, які спрямовані на розвиток розумових здібностей особистості не иляхом накопичення знань, а через розвиток дитячого мислення. Виокремлено форми організації навчання, які максимально активізували навчальнудіяльність самих учнів. Виявлено позитивні та негативні аспекти навчально-виховного прочесу в педагогічній діяльності Овідія Декролі. Вказано на можсливості використання педагогічної спадщини Овідія Декролі у сучасній педагогічній науиі та навчально-виховній практиці.

Ключові слова: Овідій Декролі; “нова школа”; навчання; виховання; дитина; вчитель; метод; розвиток; особистість.

Jim. 5.

Halyna Kemin, Ph.D. (Pedagogy), Associate Professor of the Linguistic and Intercultural Communication Department Drohobych Ivan Franko State Pedagogical University

\section{“NEW EDUCATION” THROUGH PRISM OFTHE SCIENTIFIC AND PEDAGOGICAL ACTIVITY OF OVIDIY DEKROLI}

The article deals with Ovidiy Dekroli's pedagogic works and the importance of his ideas in pedagogics of "new education". "New schools" are described. Their purpose is to educate the all-round developed initiative personality that can make decisions independently and can use the obtained knowledge in practice. Ovidiy Dekrcoli's methods of studies and education are characterised in the article. Every year hundreds of teachers and students, Dekroli's followers, attend his school to learn new methodologies and to gain the experience of creative education, that is implemented in the process of education. Dekroli's methods must develop the child's mental capacity not by knowledge accumulation, but through the development of his mindset. The forms of studies that activate the children's educational activity are distinguished here. For example, the implementation of reports is widespread in Dekroli's schools on every stage of studies. These reports are done individually by the pupils. The reports enrich the children's knowledge in industries, teach children the responsibility, help them to form their own points of view, develop their personality. Collective work is important at labour lessons. Dekroli also creates school publishing houses. So, pupils can print their newspapers and express their thoughts there. Another important type of work of Dekroli's schools, is the school correspondence among other schools, school groups, pupils. Some other positive and negative aspects of Ovidiy Dekroli 's pedagogical and educational activity are identified in the article. The ways of using Ovidiy Dekroli's experience and works into modern educational pedagogical science and educational practice are pointed out.

Keywords: Ovidiy Dekroli; "new school”; studies; an education; a child; a teacher; a method; development; personality.

A ктуальність проблеми. Радянська педагогіка в перше десятиліття свого становлення в Україні вбачала в реформаторській педагогіці знаряддя побудови нової єдиної трудової школи. Радянським педагогам імпонували ідеї “нового виховання”, які закликали до боротьби з існуючою традиційною школою. Особливо прихильно були сприйняті в Україні експериментальні дослідження, які проводилися О. Декролі [3], С. Френе [4], А. Фер'єром [5]. Разом 3 тим успішне впровадження ідей нового виховання у вітчизняну педагогіку обмежувалося як політичними, так й економічними чинниками. Реалізацію цих ідей було перекреслено репресіями, які набули масового характеру на початку 30 -их років.

Розвиток ідей “нового виховання" на західноукраїнських землях відбувався в умовах перманентної боротьби прихильників гербартіанства, які уособлювали відданість традиційним педагогічним ідеям, із представниками нових, модерних течій, в тому числі й “нового виховання”, які вважали, що стара школа вже своє віджила і суспільству потрібна 


\section{“НОВЕ ВИХОВАННЯ” ЧЕРЕЗ ПРИЗМУ НАУКОВО-ПЕДАГОГІЧНОЇ ДІЯЛЬНОСТІ ОВІДІЯ ДЕКРОЛІ}

людина нового типу, а підготувати їі може тільки “нова школа".

Аналіз останніх досліджень і публікацій. Аналіз вітчизняних досліджень засвідчив, що проблема “нового виховання” була предметом наукового зацікавлення багатьох відомих вітчизняних педагогів. Починаючи з часу виникнення, цей напрямок у педагогіці, активно вивчався А. Волошином, С. Русовою, С. Сірополком, I. Стешенком, Я. Чепігою, I. Ющишиним та іншими, які намагалися використати досвід організації “нових шкіл” з метою творення національної школи; О. Залужний, І. Соколянський, В. Протопопов, розвиваючи педологічний напрямок у вітчизняній педагогіці, намагалися адаптували його до умов вітчизняної шкільної практики; ідеї комплексності навчання на український грунт переносили такі педагоги, як Г. Іваниця, О. Музиченко, Я. Чепіга. Практична діяльність “нових шкіл” була об'єктом дослідження і в дореволюційний період. О. Джунковська, М. Левітін, О. Петрова, П. Каптєрев, О. Музиченко, О. Зеленко давали всебічну характеристику окремих шкіл “нового типу” в Англії, Німеччині, Франції, США, Швейцарії та інших країнах. Проблеми зарубіжної школи, змісту iii освіти, організації процесу навчання та виховання, методів навчання, основні тенденції їі розвитку були предметом дослідження сучасних вітчизняних та російських педагогів: Н. Абашкіної, А. Алексюка, Б. Вульфсона, О. Глузмана, М. Свтуха, В. Жуковського, Т. Кошманової, О. Кузнєцової, Т. Левченко, М. Лещенко, З. Малькової,М.Никандрова, В. Кравця, Л. Пуховської. Деякі аспекти діяльності “нових шкіл” та педагогічні погляди їх теоретиків у контексті розвитку реформаторської педагогіки та впровадження у іiі зміст гуманістичних концепцій досліджувалися упродовж останніх десятиріч такими вітчизняними педагогами, як П. Автомонов, П. Браїловська, О. Коваленко, В. Лук'янова, О. Перетятько, В. Петрова, I. Прокоп, І. Суржикова, О. Сухомлинська.

Аналіз досліджень 3 проблем зарубіжної педагогіки засвідчив, що цілісного дослідження, яке б дало всебічну характеристику педагогічної спадщини Овідія Декролі у становленні педагогіки “нового виховання”, і його впливу на розвиток національних освітніх систем в Україні не проводилося.

Метою статті $\epsilon$ проаналізувати педагогічну спадщину Овідія Декролі у становленні педагогіки “нового виховання”, визначити її вплив на розвиток національних освітніх систем в Україні, вказати на можливості використання педагогічної спадщини Овідія Декролі у сучасній педагогічній науці та навчально-виховній практиці.

Виклад основного матеріалу. Серед особливих напрямків розвитку теорії та практики “нового виховання" можна виділити організацію центрів за інтересами, метою яких було максимальне залучення дітей до інтелектуального розвитку та суспільної діяльності із врахуванням їхніх індивідуальних особливостей.

Ініціатором та автором таких центрів виступив Овідій Декролі. Спочатку він запровадив цю методику у 1901 році в школі для дітей з фізичними вадами, а в 1907 році апробував тії і в звичайних школах.

За момент відліку методики організації центрів за інтересами Декролі взяв психічний розвиток дитини. Він висунув на перше місце дитячі природні зацікавлення. При цьому важливу роль він відводив педагогу, який повинен був уважно спостерігати за певними нахилами дитини, для того щоб уміти згодом їх розвинути у навчальновиховному процесі. Основною метою створення центрів за інтересами О. Декролі вважав виховання дітей “через життя для життя”. Для досягнення цієї мети найважливішим у педагогіці Декролі виявилося створення для дитини природного середовища, у якому через спонтанні спостереження, що виникають 3 природніх зацікавлень дитини, вона здобуває основні відомості із життя людини та навколишнього середовища.

До такого середовища відносяться: майстерні, кутки живої природи, шкільний город, навчальні заняття у класних приміщеннях тощо.

Пристосовуючись до етапів психічного розвитку, дитина пізнає при цьому природне i людське середовище. Всі отримані при цьому знання розглядаються з точки зорупотреб дитини і пов'язаних із ними зацікавленнями.

Процес пізнання складається, на думку Декролі, з таких етапів: усвідомлення дітьми корисності виконуваної для людей праці; виконання різних видів діяльності для виконання цієї праці; засвоєння учнями різних знань при виконанні цієї праці [2, 32].

Аналізуючи таким чином зміст навчання, пов'язаний безпосередньо із оточенням дитини, Декролі дійшов висновку про необхідність чіткої організації навчального процесу за роками навчання.

Упродовж перших двох років навчання об'єктом зацікавлень дитини є вона сама - іiі фізичні потреби, задоволення потреби у харчуванні, а також суспільна праця. Як правило, на цьому етапі навчання теми, які обговорюються 
3 дітьми, мають не завжди плановий характер. Вони часто виникають спонтанно.

3 третього року навчання у педагога вже $\epsilon$ можливість класифікувати інтереси дітей і визначати необхідність їх включення в той чи інший центр за інтересами. При цьому кожен наступний рік навчання може мати свій центр “творчість”, “праця” та ін.

У школах, які працювали за методом О. Декролі, $\epsilon$ також предмети, що не охоплені центрами, до них належали гімнастика та співи. Навчання розпочинається від спостереження за явищами, які мають місце у житті дитини. Завданням вчителя на цьому етапі $€$ 3'ясування рівня знань дітей про той чи інший факт.

Наступним завданням учителя $є$ кореляція дитячих спостережень і проектування їх на окремий предмет. Через активну участь дитини у спостереженнях та засвоєння нею здобутої інформації відбувається процес навчання. Кінцевим етапом цього процесу є уміння використовувати здобуті знання на практиці. Їх використання має, на думку Декролі, подвійний характер: вербальний - через усні відповіді, а також творчий - малюнок, ліплення, моделювання і т.д.

Ось як виглядав урок у класі, який проводився за методом О. Декролі. Темою уроку було вибрано спостереження за ростом молодої рослини та зеленим черв'ячком, який повзе по ній. На першому етапі уроку, керованого вчителькою, діти висловлюються про свої власні спостереження. Як правило, вони говорили про рослину, яку вирощували самостійно або на території школи, або на шкільному полі. На другому етапі спостереження вони говорили про черв'ячка, його зв'язок і з цією ж рослиною, описували його зовнішній вигляд. Згодом учителька поступово перейшла до математики. Вона ставила питання: у скільки разів розмір рослини більший за розмір черв'ячка. Після активного опитування учнів одна із учениць заміряла лінійкою довжину рослини і черв'ячка. Інший учень на дошці наніс відповідну довжину у співвідношенні. При цьому діти разом із вчителькою коментували свої помилки, а також виконували різні арифметичні дії: додавання, віднімання, множення, ділення. Кожен прагнув переконатися, наскільки він помилився у виконанні завдання [2, 35].

На уроці інтенсивно використовувалися різні унаочнення як $з$ ботаніки, так і зоології та математики. Пізніше вчителька перейшла до наступного етапу уроку - філологічного. Тут було задіяно двох учнів, - один з яких виконував роль рослини, інший - роль черв'ячка. Керуючи діалогами, вчителька скеровувала дітей на пошук відмінностей і спільних властивостей між цими двома представниками живого світу. Цей діалог між учнями було записано на дошці. Учням необхідно було закрити очі і знайти заголовки до цього діалогу. Таким чином відбувалося тренування дитячої уяви. Нарешті всі учні разом iз учителькою зачитували цей діалог, а потім аналізували окремі невідомі їм слова.

Зацікавленість та активність учнів протягом всього заняття були очевидними. Така організація навчального процесу давала можливість усім учням бути його учасниками. Практично не залишалося дитини, яка б не брала участі у різних видах діяльності, де елементи праці перепліталися 3 елементами гри. Завдяки організації навчання через центри за інтересами навчальний процес проходив за схемою: спостереження - вираження.

Особливістю роботи шкіл, які працювали за методом О. Декролі, було те, що у них не використовували підручників. Найважливішим джерелом інформації для учнів замість підручника став щоденник власних спостережень. Він був покликаний виконувати роль традиційного підручника, але відрізнявся від нього обсягами інформації, яку учні отримали у процесі навчання $[2,42]$.

Як правило, учні вели одночасно декілька щоденників, нагромаджуючи інформацію, що відповідала традиційним предметам шкільного виховання. Аналогічно відбувалася й організація навчання читання та письма. Вимову слова вчитель записував на дошці, а діти у зошитах. Саме зошит ставав для них основним джерелом знань 3 мови.

У старших класах, де діти вже опановують техніку читання і письма, досить широко застосовувалася інтерпретація текстів. Дії, пов'язані з нею, виконувалися під керівництвом учителя під час практичних занять. Ці тексти містили у собі основні відомості з різних предметів. Одним із основних своїх завдань методика організації центрів за інтересами ставила завдання розвитку самодіяльності учнів у навчальному процесі. При цьомувся інформація, засвоєна учнями, повинна була ними використовуватися у практичній діяльності.

Надзвичайно поширеним видом самодіяльності роботи в школах О. Декролі було виконання рефератів на кожному етапі навчання.

Діти молодшого шкільного віку повинні були виконувати цю роботу на основі власних спостережень. Їм, для прикладу, пропонувалося дати відповіді на такі питання, як “Що ти знаєш 
про бджолу?”, “Які ознаки початку весни у природі?” тощо. Діти старшого віку повинні були виконувати реферати на більш складну тематику: “Життя ескімосів", “Людина і природа". Підготовлені реферати діти зачитували перед усім класом, відбувалося їх жваве обговорення.

Ці реферати, крім того що збагачували знання учнів з певних галузей, вчили їх формувати власну життєву позицію, відповідальності, сприяли всебічному розвитку [2, 48].

Для вчителів, які працювали за методикою організації центрів за інтересами, у навчальному процесі виникало багато труднощів. Основною проблемою для них був вибір предмета для спостереження. Тут йшлося про те, щоб спостереження не було створено штучно. Необхідно було дібрати такий предмет для спостереження, який би будив зацікавленість учня, водночас це мав бути програмний матеріал, який би відповідав певному етапу навчання $[2,50]$.

Упровадження методу організації навчання за центрами за інтересами відбувалося особливо інтенсивно у 20-х роках ХХ століття. У 1920 році воно було введено у 12 комунальних школах Брюсселя. Пізніше у 1922/23 рр. місцева влада ввела його в усіх початкових школах міста. До загальнодержавних програм цей метод було введено у 1936 р. На всій території Бельгії цей метод було визнано на загальнодержавному рівні $[1,72]$.

Цікавим $є$ той факт, що методика Декролі у Бельгії була не настільки відомою, як за тї межами. Тривалий час їі ефективність визнавали у всьому світі, а в Бельгії тільки з 1936 року. Ця програма $з$ ентузіазмом була прийнята відомими прогресивними педагогами того часу (Піаже, Фер'єр, Валлон).

У чому ж полягала іiі революційність? Перш за все в тому, що ця програма мала потужну наукову базу, в основі якої були найновіші досягнення з педагогіки, психології та інших наук. Відмінність цієї програми від інших полягала не в iii змісті (фактично навчальний матеріал залишався незмінним), а в ревізії методу навчання. Тобто відбувався корінний перегляд всього дидактичного процесу. В основі нової програми були дві засадничі ідеї: наближення навчання до життя та впровадження глобального методу в навчанні читання та письма.

Основним дидактичним засобом стало живе спостереження. Такий радикальний поворот до активізації навчального процесу був надзвичайно складним для вчителів, які працювали за цим методом. Більшість із них були вихована на традиційних дидактичних методах і навіть не розуміла самих понять нової програми. Не було нічого дивного в тому, що спочатку вони ставилися досить скептично до нових програм, а це коштувало чималих зусиль авторам програм, щоб залучити для їх реалізації педагогічну громадськість. В умовах Бельгії вирішальним фактором, який зіграв на користь прихильників течії “нового виховання”, була та обставина, що їі активно підтримали шкільні інспектори. Саме їм належить заслуга в тому, що вони зуміли об'єднати навколо себе всіх ентузіастів нової педагогіки й організувати їх для запровадження нових методів ушкільну практику. Внаслідок цього реформаторські ідеї було зреалізовано на державному рівні в умовах всієї країни.

3 часом, коли перший ентузіазм пройшов, виявилося, що програма Декролі має і певні недоліки. На першому етапі здавалося, що причиною невдач $є$ недостатня підготовленість до роботи в нових умовах педагогічних кадрів. Згодом виявилося, що існують вагоміші причини. Зосередження навчального матеріалу навколо центрів за інтересами, а не як в програмах 3 окремих предметів, передбачало ігнорування принципу систематичності у навчанні та ускладнювало засвоєння знань у логічній послідовності. Тільки досвідчені педагоги, які глибоко перейнялися ідеями нового виховання, могли зреалізувати на практиці його головні засади: навчання в центрах та володіння енциклопедичним навчальним матеріалом. Саме ці засади стали об'єктом найбільшої критики 3 боку опонентів як в Бельгії, так і за ії межами.

Висуваючи на перший план потреби та зацікавлення дітей, методика організації навчання за інтересами фактично ставала на засади педоцентризму. Базові шкільні дисципліни підпорядковувалися в ній виключно самодіяльним дослідницьким ідеям учнів. Концентрація навчального матеріалу навколо тем, що виражають тільки потреби та зацікавлення учнів, призводила до занедбання систематичності навчання, тому що кожна галузь знань має свою, на думку противників цього методу навчання, структуру і повинна бути відображена у шкільній програмі дисциплін.

Завдання школи не можна було обмежувати тільки розвитком учнівської самодіяльності, адже школа виконує також важливу функцію ознайомлення молодого покоління 3 існуючою культурною традицією.

В умовах роботи шкіл за методом центрів за інтересами останню функцію було досить важко зреалізувати через те, що було зігноровано логічну структуру базових шкільних дисциплін. Навчання 
відривалося від навчального системного курсу i не давало учням необхідного мінімуму знань 3 цього курсу, які б були викладені у логічній послідовності, що давало б учням можливість накопичувати ці знання у період їхнього навчання у середній школі $[1,146]$.

Зазначені недоліки педагогіки О. Декролі спонукали його до спроби ії̈ вдосконалення. Були намагання вдосконалити основу цієї методики: наблизити навчання до середовища та використати дитячі зацікавлення для вдосконалення навчального процесу. Одночасно робилися спроби пристосувати цю методику до структури навчальних дисциплін.

Зокрема, у 1936 році комунальні школи Брюсселя зробили спробу переглянути методику організації навчання через центри за інтересами. Це призвело до віддалення цієї методики від іiі первісного вигляду. У незмінному вигляді вони залишалися тільки в тих школах, які були засновані О. Декролі і його найближчими соратниками та послідовниками. Незважаючи на те, що у них працювали висококваліфіковані педагоги із відомими іменами та новаторськими підходами до організації навчального процесу, кількість учнів у цих школах поступово зменшувалася через високу оплату. Це призвело до того, що ці школи стали доступними тільки для заможних членів суспільства.

У той же час брюссельські комунальні школи 3 часом відійшли від методики організації навчання через центри за інтересами. У 1953 році бельгійська влада прийняла нову програму початкового навчання, у якій підкреслювалася важливість розвитку у дітей інтересів, але разом 3 тим більше уваги приділялося на засвоєння учнями систематичних знань про навколишній світ. Тому методику організації центрів за інтересами визнали доцільною для використання тільки на початковому етапі навчання.

Еволюція програми навчання для бельгійських початкових шкіл не означала відмову від педагогічних принципів О. Декролі. Навпаки, ці принципи лягли в основу удосконаленої навчальної програми, яка прагнула усунути ті недоліки, які були в першій програмі. Ця програма була більше скерована на послідовність та систематичність у навчанні.

3 прийняттям нових програм у Бельгії початкове навчання стало організовуватися в атмосфері реалізму та доступності. Завдяки такій еволюції реалізація педагогіки О. Декролі набула цілком нової якості - раціоналізації центрів за інтересами. Цей удосконалений метод зблизив навчання 3 життям та середовищем дитини, через свою видовищність він активізував навчальну діяльність учнів. Тогочасна початкова школа у Бельгії підтвердила правильність обраного шляху. Усунувши загрозу надзвичайної концентрації навчального матеріалу навколо центрів за інтересами, початкова школа зберегла у себе ті активні методи навчання, які були притаманні експериментальним школам О. Декролі, оптимізувавши мету навчання та надавши їй творчого характеру.

Багато корисного від педагогіки О. Декролі було збережено і при організації трудового навчання. Тут на перше місце ставився колективний підхід. Колектив класу, групи, організовувався на виконання певних видів робіт: столярство, рільництво, тваринництво. Ці види робіт урізноманітнювалися індивідуальними формами трудового навчання.

Заслуговує на увагу і досвід шкіл О. Декролі щодо створення шкільних друкарень, які дозволяли учням не тільки видавати власну газету, але й формувати у них певні переконання.

Ще один важливий вид роботи, який був започаткований у школах О. Декролі, - це шкільне листування. Листування між школами, учнівськими колективами, окремими учнями, на думку О. Декролі, повинно було активізувати в учнів бажання робити добрі справи і розповідати про це іншим. У цьому листуванні учні прагнули якнайретельніше описати те позитивне, що було зроблено їхнім колективом за певний період. Вони цікавилися, а як це робиться в інших.

Незважаючи на те, що педагогіка О. Декролі не була повністю зреалізована у всіх школах Бельгії у відповідний період, незаперечним $\epsilon$ той факт, що саме Бельгія стала у 20 - 30-х рр. країною, де найбільш інтенсивно розвивалася педагогічна наука. Щороку тут організовувалися “semaines pйdogogiques" (педагогічні тижні), до участі в них зголошувалися відомі педагоги 3 усього світу. Тут обговорювалися найсучасніші педагогічні технології, висувалися нові ідеї. Саме, завдячуючи О. Декролі Бельгія стала на деякий час “педагогічною Меккою”, куди прагнув потрапити кожен учений-педагог.

Заснована у 1907 р. О. Декролі школа Ермітаж у Бельгії продовжує свою педагогічну діяльність і сьогодні, перетворившись у всесвітньовідомий центр декроліани. Навчально-виховний процес у школі організований за зразком відомого педагога. Досвід експериментальної роботи школи вивчається у багатьох країнах світу. На початку XX ст. ушколі нараховувалося більше однієї тисячі студентів. До складу школи входять дитячий садок, початкова та середня школи. Кожного року 
сотні вчителів та студентів, послідовників О. Декролі, відвідують цю школу, щоб вивчити нові методики навчання, досвід креативної педагогіки, яка активно впроваджується у навчально-виховний процес. Школа організовує наукові конференції, виставки, зустрічі, присвячені актуальним проблемам навчання та виховання дітей. Вона $\epsilon$ також ініціатором міжнародних педагогічних читань “Дні О. Декролі” та учасником міжнародних конгресів: це - ювілейний міжнародний конгрес присвячений 100-річчю від дня народження О. Декролі, Брюссель 1971; Міжнародна виставка “Доктор Декролі i виховання” (1971); Науковий колоквіум "Психологія та інноватика у школі”; “О. Декролі і сучасність” (1983), Експозиція “Cuatro Pedagogos: Montessori - Decroly - Piaget - Freinet" (Барселона, 1988).

Школа Ермітаж видає "Педагогічні документи” та “Зошити декроліани”, у яких публікуються результати експериментальних досліджень галузі педагогіки та психології.

Висновки. Розвиток ідей “нового виховання" на західноукраїнських землях відбувався в умовах перманентної боротьби прихильників гербартіанства, які уособлювали відданість традиційним педагогічним ідеям, із представниками нових, модерних течій, в тому числі й “нового виховання”, які вважали, що стара школа своє уже віджила і суспільству потрібна людина нового типу, а підготувати їі може тільки “нова школа". Багато ідей із творчого доробку педагогіки нового виховання не втратили своєї актуальності і сьогодні. На даний час у світі існує багато інституцій та шкіл, які продовжують традиції “нового виховання" та вивчають педагогічну спадщинуО. Декролі інших педагогів. У Західній Свропі, Південній та Північній Америці існує мережа сучасних шкіл, які є спадкоємцями “нових шкіл”, заснованих всесвітньовідомими педагогами. Їх досвід залишається актуальним і для вітчизняної освіти. Це стосується передусім індивідуалізації та диференціації навчання; впровадження у шкільну практику ефективних педагогічних методів i засобів розвитку пізнавальних здібностей учнів; досвіду роботи 3 обдарованими дітьми; методики навчання окремих дисциплін (мови, природознавчі дисципліни); розвиткушкільного самоврядування.

\section{ЛІТЕРАТУРА}

1. Besse J.-M. Decroly, psychologue et éducateur. - Toulouse: Privat, 1982. - 180 p.

2. Decroly O. L'école active par la méthode Decroly / O. Decroly. - Bruxelles: Mamertin, 1930. $-65 \mathrm{p}$.

3. Decroly O. La fonction de globalisation et l'enseignement. - Hamelin, 1929. - 77 p.

4. Ferrier A. L'école Active / A. Ferrier. Genève. -1922 -T.2. - 380p.

5. Freinet C. Naissance d'une pédagogie populaire. - Historique de la CEL / C. Freinet. Cennes, 1949. - 125 p.

\section{REFERENCES}

1.Besse, J. (1982). O. Decroly, psychologue et éducateur [O. Decroly, psycologist and educator]. Toulouse: Privat, 180 p. [in French].

2.Decroly, O. (1930). L'école active par la méthode Decroly [Active Schools according to Dercoly's Methods]. Bruxelles: Mamertin, 65 p.[in French].

3.Decroly, O. (1929). La fonction de globalisation et l'enseignement [Functions of globalization and education]. Hamelin, 77 p. [in French].

4.Ferrier, A. (1922). L'école Active [Active School]. Genève,vol.2, 380p.[in French].

5.Freinet, C. (1949). Naissance d'une pédagogie populaire [The Birth of Popular Education]. Historique de la CEL. Cennes, 125 p.[in French].

Стаття надійшла до редакції 29.10.2018

\section{G58080.2058080}

"Хто хоче багато досягти, повинен ставити великі вимоги".

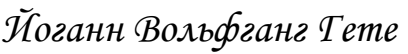

німецький поет, прозаїк драматург

"Жбо може бути чесніше $і$ благороднішим, як навчити інших тому, що сам найқращим чином знаєщ?"

МаркФабій Квінтіліан

давньоримський оратор

\section{G5808nc2058080}

